\title{
Lapurdum
}

LAPURDUM Euskal ikerketen aldizkaria | Revue d'études basques |

Revista de estudios vascos | Basque studies review

$10 \mid 2005$

Numéro $X$

\section{Testuinguruak murriztutako kuantifikazioa}

\section{Urtzi Etxeberria}

\section{OpenEdition \\ Journals}

\section{Édition électronique}

URL : http://journals.openedition.org/lapurdum/42

DOI : $10.4000 /$ lapurdum.42

ISSN : 1965-0655

\section{Éditeur}

IKER

Édition imprimée

Date de publication : 31 décembre 2005

Pagination : 35-64

ISBN : 2-86781-409-X

ISSN : $1273-3830$

\section{Référence électronique}

Urtzi Etxeberria, «Testuinguruak murriztutako kuantifikazioa », Lapurdum [Linean], 10 | 2005, Sarean emana----an 01 avril 2008, kontsultatu 19 septembre 2020. URL : http://journals.openedition.org/ lapurdum/42 ; DOI : https://doi.org/10.4000/lapurdum.42 


\author{
Urtzi Etxeberria \\ (CNRS-UMR5478 / HiTT)
}

\title{
Testuinguruak murriztutako kuantifikazioa ${ }^{1}$
}

\section{Sarrera}

Lan honek, euskarako zenbatzaile sendoak deituak izan direnentzat (ikus Etxeberria 2002, 2004, 2005) analisi konposizional berri bat proposatzen du. Bertan proposatzen den analisiak Zenbatzaile Orokortuen Teoria estandarrak hizkuntza naturaletako kuantifikazioa azaltzeko ahalmena baduela erakusten digu (pace Matthewson 2001).

Kuantifikazioaren analisi estandarrak multzoen multzo bat denotatzen duen zenbatzaile orokortu (ZO) baten konposizionaltasuna kuantifikatzailedeterminatzaile $^{2}$ (Kdet) eta Izen Sintagma (IS) baten konbinaketatik sortzen dela dio (ikus Montague 1973, Barwise \& Cooper 1981, Keenan \& Stavi 1986). (1)-eko etsenpluan ingeleseko every student $\mathrm{ZO}-\mathrm{a},\langle\langle\mathrm{e}, \mathrm{t}\rangle, \mathrm{t}\rangle$ tipo semantikoa duena, $\langle\langle\mathrm{e}, \mathrm{t}\rangle,\langle\langle\mathrm{e}$, $\mathrm{t}\rangle, \mathrm{t}\rangle\rangle$ tipoko every Kdet-a eta $\langle\mathrm{e}, \mathrm{t}\rangle$ tipoko student izenaren konbinaketatik sortzen da.

$$
\begin{gathered}
\begin{array}{c}
\text { [K-dets every } \\
\text { guzti/bakoitz ikasle } \\
\text { 'Ikasle guztiak/bakoitza' }
\end{array} \\
\frac{\mathrm{K}-\operatorname{det} S\langle\langle\mathrm{e}, \mathrm{t}\rangle, \mathrm{t}\rangle}{\mathrm{K}-\operatorname{det}\langle\langle\mathrm{e}, \mathrm{t}\rangle,\langle\langle\mathrm{e}, \mathrm{t}\rangle, \mathrm{t}\rangle\rangle \quad \mathrm{IS}}\langle\mathrm{e}, \mathrm{t}\rangle
\end{gathered}
$$

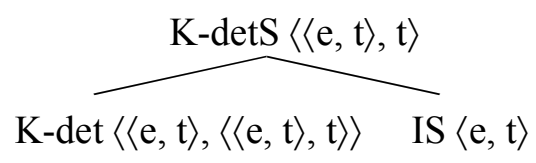

Analisi honek semantika formalaren usadioan onarpen haundia izan duen arren, hizkuntza batzuk (1)-eko egiturarik ez daukatela argudiatu izan da. Matthewson-ek (2001) esaterako, st'át'imcets hizkuntza saliziarreko zenbatzaileez berak buruturiko ikerketan oinarrituz, hizkuntza naturaletako kuantifikazioa bi

\footnotetext{
1 Jende askoren laguntza jaso dut artikulu hau idazteko garaian. Bereziki Ricardo Etxepare eta Fernando Garcia Murgari eman nahi nizkieke eskerrak. Eskerrak baita ere Maia Duguine, Anastasia Giannakidou, Aritz Irurtzun, Brenda Laca, Utpal Lahiri, Joseba Lakarra, Richard Larson, Louise McNally, Luisa Martí, Javier Ormazabal, Juan Uriagereka eta Myriam Uribe-Etxebarriari. Ikerketa hau Eusko Jaurlaritzaren BFI05.115 ikerketa bekaren eta Euskal Herriko Unibertsitateko 9/UPV 00114.130-16009/2004 ikerketa proiektuaren laguntzari esker burutu ahal izan da.

${ }^{2}$ ZO teoria estandarrean, kuantifikatzaile Kuantifikatzaile Sintagma osoari deitzen zaio, zenbatzaileari berari Determinatzaile deitzen zaion bitartean. Lan honek ZO teoria estandarra asumitzen duenez (aurrerago ikusiko dugunez) Kuantifikatzaile-Determinatzaile (Kdet) terminoa erabiliko dut zenbatzaileari erreferentzia egiteko garaian.

${ }^{3}$ Analisi zehatzago baten beharrean gaude euskaraz ingeleseko every-ren parekorik ba ote dagoen (eta hala bada, zein den) jakiteko.
} 
urratsetan eman behar dela proposatzen du: lehenengo, Determinatzailea (D) IS-rekin batzen da entitate bat denotatzen duen $e$ tipoko elementu bat sortuz; eta bigarren urrats batean, Kdet-ak (kasu honetan $\langle\mathrm{e},\langle\langle\mathrm{e}, \mathrm{t}\rangle, \mathrm{t}\rangle\rangle$ tipokoa izango denak) sorturiko objektu hau argumentu gisa hartzen du ZO bat sortuz. Ohar gaitezen (2b)-n eskeintzen den egituran, Kdet-a e tipoko elementu batekin konbinatzen dela, kuantifikazioaren teoria estandarrak dionaren kontra.

(2a) [K-dets tákem $i \quad$ smelhmúlhats-a]

[ guzti D.pl emakume(pl)-D]

'Emakume guztiak'

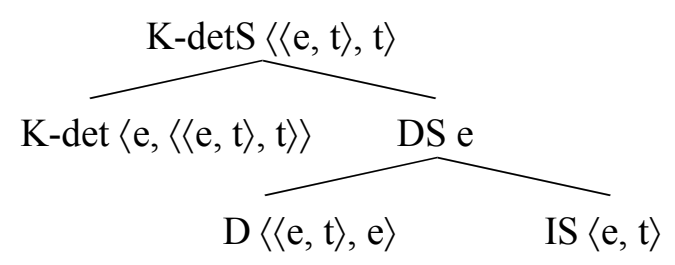

Halere, duela gutxiko artikulu batean, Giannakidou-k (2004) Matthewson-en (2001) aurreikuspen nagusiek arazoak dituztela erakusten du eta ondokoa argudiatzen: (i) KdetS barneko D-a izenaren dominioaren murriztatzaile bat da, (ii) hizkuntzen artean desberdintasunak daude kuantifikazioaren murriztapen hau agerian ala ezkutuan egiten den (ikus baita ere Etxeberria 2004). Ondorioz, ZO-en analisi estandarrak hizkuntzaz hizkuntzako kuantifikazioa azaltzeko ahalmena du (pace Matthewson 2001)

Artikulu honek euskarako zenbatzaile sendo-entzat analisi konposizional berri eta berritzaile bat proposatzen du, Giannakidou-ren (2004) analisi teorikoa bermatuz. Helburu honekin, euskarazko zenbatzaileen datuak erakutsiko dira, zeinak argiro erakusten baitute dominioaren murriztapena Kdet-ean (Westerståhl 1985, von Fintel 1994, Martí 2003) zein izenean (Stanley \& Szabó 2000, Stanley 2002) ager daitekeela. Batean edo bestean agertzea zenbatzaileak lexikoki sendoak (§3.2.1) ala eratorritako zenbatzaile sendoak (\$3.2.2) izatearen ondorio izango da. Erabakigarriro, euskaraz, dominioaren murriztatzailea den D-a zenbatzaile sendoekin bakarrik agertzen da, zenbatzaile ahulekin erabat bateraezina den bitartean. Propietate hau, zenbatzaile ahulak ez direla ez zenbatzaile ez eta testuinguruak murriztutako elementuak erakustera dator (cf. Milsark 1979, Partee 1988, Cooper 1996, von Fintel 1998). Zenbatzaile ahulen analisi konposizionala ere aurkezten du lan honek, non 〈e, t) tipo predikatiboan sortzen direla proposatzen den.

Artikulua jarraian azaltzen den moduan dago antolatua: 1. atalean, ZO-en analisi alternatiboak dituen ondorio deseroso batzuk erakusten dira. 2. atalak testuinguru aldagaien inguruan sorturiko eztabaidan jartzen du arreta jarraian Giannakidou-ren proposamena aurkeztuz, non testuinguru aldagaia Kdet-ari zein izenari atxikiturik ager daitekeela defendatzen den. 3. atalean euskarazko datuak aurkezteaz gain euskal zenbatzaile sendo zein IS ahulen analisi berri eta berritzaile bat proposatu eta defendatzen da. 


\section{Kuantifikazioaren analisi alternatiboa eta beraren arazoak}

Giannakidou-k (2004), Matthewson-en (2001) aurreikuspen nagusiek arazoak dituztela erakusten du, eta haren analisia ((2b)-n) ezin dela hizkuntzaz hizkuntza zabaldu:

\subsection{St'át'imcets-eko DS-ak e tipoko elementu bezala interpretatu behar dira}

St'át'imcets-en, D etenak irakurketa definitua zein indefinitua izan ditzakeen DS-ak sortzen ditu.
a. q'wez-ílc [ti smúlhats-a] dantza-intr. [D emakume-D]
'Emakume-ak/batek dantza egin zuen.'
(Matthewson 2001: (13))
b. dantza egin (f(emakume)): emakumeen multzotik testuinguruan nabarmena den f funtzioa erabiliz aukeratua izan den emakumeak dantza egin zuen.

Definitutasun/indefinitutasun desberdintasunik ez dagoenez st'át'imcets-eko determinatzaileetan (ch Matthewson 1999, 2001), Matthewson-ek DS hauek itxiera esistentziala mailarik altuenean jasoko luketen hautatze funtzio moduan interpretatutako indefinitutzat tratatzea erabakitzen du (ikus Matthewson 1999: 109). ${ }^{4}$ Honela, D-a predikatu batekin konbinatuko da predikatu hori asebetetzen duen banako horietatik bat bueltatuz.

$$
\left[\left[X \ldots a_{k}\right]\right]^{\mathrm{g}}=\lambda \mathrm{f} \in \mathrm{D}_{\langle\mathrm{e}, \mathrm{t}\rangle} \cdot(\mathrm{g}(\mathrm{k}))(\mathrm{f})
$$

(Matthewson 2001: (18))

D-ren indizeak zein hautatze funtzio erabiliko den zehazten du (4)-n; g indizeetatik hautatze funtzioetarako esleipen funtzio bat da eta $\mathrm{g}(\mathrm{k})\langle\mathrm{e},\langle\mathrm{e}, \mathrm{t}\rangle\rangle$ tipoko hautatze funtzio bat izango da.

St'át'imcets-eko D-a horrela tratatzeak ordea definituen pareko egiten du: Itxiera esistentziala mailarik altuenean jasoko duen hautatze funtzio bat DS erreferentzial baten pareko da (ikus (3b)-n jasotzen duen interpretazioa (Matthewson 2001:152-tik hartua)). Hau da, testuinguruan nabarmena den hautatze funtzio bat denotatzen duen DS bat definitu moduan tratatu beharko litzateke; IS asebetetzen duen indibiduo atomiko bakar bat (edo pluralen kasuan IS-k denotatzen duen batuketa maximoa) ematen duen maximotasun (eta unizitate) funtzio baten pareko baita.

Are gehiago, Matthewson-en analisiak aurrikusten du st'át'imcets-eko DS-ak beti $e$ tipoko entitateak denotatuko lituzkeen elementu gisa interpretatu behar direla eta tipo-aldaketarik (type-shifting) inoiz ez dutela jasango (ez predikatu ez kuantifikazio tipora); eta hau Partee-k (1987) defendatutako eta oinarri sendoak dituen proposamenaren aurkakoa da, non hizkuntza naturaletako DS-ek (definitu zein indefinituek) predikatu eta kuantifikaziorako tipo-aldaketa arazorik gabe egin dezaketela erakusten den.

\footnotetext{
${ }^{4}$ Hautatze funtzioa esistentzialki mailarik altuenean itxi behar dela Matthewson-ek (1999) st'át'imcetserako proposatzen du bereziki. Badira hautatze funtzioa ia edozein mailatan interpreta daitekeela argudiatzen duten hizkuntzalariak ere (ikus adb. Reinhart 1997, Winter 1997, Kratzer 1998).
} 


\subsection{Kdet-ak ez dira definituekin konbinatzen}

Matthewson-en analisiak hizkuntzaz-hizkuntza Kdet-ak definituekin konbina daitezkeela aurreikusten du. Datuek ordea, ez dute aurreikuspen hau berresten.

Ingelesa:
(5a) * every the boy
lit.: 'bakoitz D mutil(pl)'
(5b) * most the boys
lit.: 'gehien D mutil(pl)'
(5f) all the boys
lit.: 'guzti D mutil(pl)'
(5g) only the boys
(5c) * many the boys
lit.: 'asko D mutil(pl)'
(5d) * three the boys
lit.: 'bakarrik D mutil(pl)'
lit.: 'hiru D mutil(pl)'

Espainola:
(6a) * cada los chicos
lit.: 'bakoitz D mutil(pl)'
(6b) * pocos los chicos
lit.: 'gutxi D mutil(pl)'
(6c) * muchos los chicos
lit.: 'asko D mutil(pl)'
(6d) * tres los chicos
lit.: 'hiru D mutil(pl)'
Grekera (Giannakidou 2004):
(7a) * kathe to aghori
lit.: 'bakoitz D mutil(sg)'
(7b) * merika ta aghoria
lit.: 'ugari D mutil(pl)'
(7c) * tria ta aghoria
lit.: 'hiru D mutil(pl)'
(6f) todos los chicos
lit.: 'guzti D mutil(pl)'

(6g) sólo los chicos

lit.: 'bakarrik D mutil(pl)'
(7d) ola ta agoria
lit.: 'guzti D mutil(pl)'
(7e) mono ta aghoria
lit.: 'bakarrik D mutil(pl)'

(5-6-7)-ko etsenplu gramatikalak, (2b)-ko egituraren bitartez irudikatu daitezkeenak, ingeleseko all eta only-ren pareko elementuekin osatuak daude. Elementu hauek ez direla zenbatzaileak esan izan da. All (+DS) osotasun operatzaile baten semantika lukeen DS modifikatzaile moduan analizatua izan da (Brisson 1998, 2003), eta only proposizio operatzaile gisa tratatua izan da (adb. von Fintel 1997). Ohar moduan, goiko etsenplu ez-gramatikal asko automatikoki gramatikal bihurtzen dira preposizio partitiboa (ingeleseko of esaterako) sartzen dugunean (many of the boys, three of the boys).

\section{3. 'of' partitiboak esanahi semantikoa du}

Kdet-ak $e$ tipoko entitatea denotatzen duten elementuekin konbinatzen badira, ingeleseko many of the students bezalako egituretako of partitiboak semantikoki 
esanahi gabea izan behar du (pace Ladusaw 1982)) st'át'imcets hizkuntzarentzako proposatu den (2b)-ko egitura hizkuntzaz hizkuntza baliagarria izan behar bada.

Matthewson-en arabera, (8)-ko egituretako preposizio partitiboaren presentzia kasu arrazoiei zor zaio soilik.

(8a) Many of the politicians did not tell the truth. asko -tik D politikari(pl) aux ez esan D egi 'Politikarietatik askok ez zuten egia esan.'

(8b) Some of the policemen dedicated the whole day to fine drivers. batzuk -tik D polizi(pl) dedikatu D oso egun -ko isundu gidari 'Polizietatik askok egun osoa isunak jartzen igaro zuten.'

Dena den, asuntzio honek zenbait arazo ditu: hasteko, ingeleseko of hautazkoa da hainbat egituretan, eta honek ez luke horrela izan behar of kasu markatzaile hutsa balitz.

(9a) all (of) the boys guzti (-tik) $\mathrm{D}$ mutil(pl)

(9b) half (of) the boys erdi (-tik) D mutil(pl)

(9c) both (of) the boys biak (-tik) D mutil(pl)

Zulu hizkuntzako datuek ere of kasu markatzaile moduan bakarrik ezin egon daitekeela erakusten dute (ikus Adams 2005). ${ }^{6}$ Hurrengo esaldi gramatikaletan of-en homologoa den $b$ - (ikus (10b)) hautazkoa da eta bere presentziak edo ausentziak aldaketa dakar esanahiean.

(10a) Aba-fana aba-ningi ba-ya-dla. cl2-mutil cl2-asko cl2-pres-jan 'Mutil asko jaten ari dira.'

(10b) Aba-ningi b-aba-fana ba-ya-dla. cl2-asko cl2part-cl2-mutil cl2-pres-jan 'Mutiletatik asko jaten ari dira.'

Gainera, Matthewson-en (2001) esanetan st'át'imcets-ek (of-en parekorik ez duen hizkuntza) ageriko kasu markarik ez izateak of kasu markatzaile soila izatearen proposamena bermatzen du. Zulu-k, st'át'imcets hizkuntzak bezalaxe, ez du ageriko kasu markarik baina bai of-en pareko partitiborik (10b)-k erakusten duen moduan.

\subsection{Kdet eta D-aren posizio aldakorra}

Matthewson-en analisiak DS-ak Kdet-en osagarri direla aurreikusten du. Hala ere, bi hurrenkerak ([Kdet [DS]] eta [D [Kdet]]) erakusten dituzten hizkuntzak ere badira. Honek erakutsiko luke Kdet-ek ez dituztela beti $e$ tipoko DS-ak hartzen osagarritzat.

\footnotetext{
${ }^{5}$ Baita beste hizkuntzetako pareko egituretako partitiboak ere.

${ }^{6}$ Eskerrak Nikki Adams-i zuluerako datuen berri emateagatik.
} 
St'át'imcets-eko zenbatzaile gehienek DS-ak hartzen badituzte ere osagarri gisa, bere (2b)-ko egitura kuantifikazionala bermatzen ez duten datuak (ikus (12a-b)) ere aurkezten ditu Matthewson berak.

(11a) tákem i smelhmúlhats-a [K-det [DS]] guzti D.pl emakume(pl)-D 'emakume guztiak'

(11b) zi7zeg' i sk'wemk'úk'wm'it-a [K-det [DS]] bakoitz D.pl ume(pl)-D

'ume bakoitza'

(12a) i tákem-a smúlhats D.pl guzti-D emakume 'emakume guztiak'

(12b) i zí7zeg'-a sk'wemk'úk'wm’it D.pl bakoitz-D ume(pl) 'ume bakoitza'

[D [K-det]]

(Matthewson 2001: 5. oinoharra)

[D [K-det]]

(Matthewson 1999: (41c))

Giannakidou-k (2004) erakusten duen bezala, grekeraz ere aurki daitezke Kdet-a D-aren azpian agertzen diren adibideak, (13b)-n ikus daitekeenez.

Oli i fitites
guzti D.pl ikasle(pl)
'ikasle guztiak'

(13b) O kathe fititis D.sg bakoitz ikasle(sg) 'ikasle bakoitza'
[K-det [DS]]

[D [K-det]]

(Giannakidou 2004: (32b))

Euskarako zenbatzaileak ere bi egitura hauek esistitzen direnaren aldeko ebidentziatzat har daitezke: lexikoki sendoak diren Kdet-ak zuzenean D-arekin konbinatzen dira (ikus 3.2.1 atala), eta ez beraien osagarri nominalarekin Matthewson-ek defendatze duenaren aurka.

(14a) Mutil guzti-ak

[[K-det $]$ D] $(=[\mathrm{D}[\mathrm{K}-$ det $]])$

(14b) Mutil bakoitz-a [[K-det] D] (=[D [K-det] $])$

Arazo guzti hauek ikusita, Giannakidou-k (2004) zenbatzaile orokortuen analisi estandarraren alde egiten duen eta ondorengoa dioen proposamen berri bat plazaratzen du:

(i) KdetS barneko D-ak (izenaren) dominioaren murriztatzailearen funtzioa betetzen du (ikus baita ere Etxeberria 2004),

(ii) dominioaren murriztatzaileak Kdet-ean bertan ere ager daitezke,

(iii) hizkuntzak kuantifikazioaren dominioa agerian ala ezkutuan murrizten duten desberdintzen dira,

(iv) ZO-en analisia estandarrak hizkuntza naturaletako kuantifikazioa azaltzeko ahalmena du 
Proposamenaren xehetasunak azaldu aurretik, hurrengo atala lan honetan egingo diren asuntziorik garrantzitsuenetako bat aurkeztera dator: testuinguru aldagaiek errealizazio sintaktikoa dutela (agerikoa ala ezkutukoa).

\section{Testuinguruak murriztutako dominioaren gaineko eztabaida}

Testuinguru aldagaiek testuingurutik jasotzen dute beren balioa eta eginkizun oso garrantzitsua dute hizkuntza naturaletako kuantifikazioan ( $C$-z adierazia (15)-n). Izan ere, bada zenbatzaile guztiak testuinguruak (ezkutuko) testuinguru aldagai batekin Forma Logikoan (FL) hornitzen ditueneko asuntzio orokor bat. ${ }^{7}$

Imajina dezagun (15) bezalako egoera bat:

(15) [A hiztuna B hiztunari atzo gaueko afariaren berri ematen ari zaio, A eta beraren ikasle batzuk pizzeria batetara joan zirenekoa]
A: Everybody ${ }_{C}$ had a great time
(von Fintel 1994: 28)

Etsenplu honetan, A hiztunak ez du mundu guztiak, literalki, momentu oso ona pasa zueneko ideia adierazteko asmorik. Aldiz, (15) bezalako esaldi bat testuinguruak murriztutako indibiduo multzo bati buruz ari da, bart A-rekin pizzeriara joan zen multzoari buruz hain zuzen ere.

Beste asuntzio orokor batek zenbatzaileen dominioaren murriztapena sintaktikoki gauzatzen dela dio ('explicit strategy' Neale-n 1990). Hala ere, bada auzi ireki bat, testuinguru aldagaia zehazki non gauzatzen den. Autore batzuen arabera (ezkutuko) testuinguru aldagaia izenean gauzatzen den bitartean (Stanley \& Szabó 2000, Stanley 2002), beste autore batzuk testuinguru aldagaia Kdet-arekin batera gauzatzen dela defendatzen dute (von Fintel 1994, Martí 2003).

Artikulu honetan, dominioaren murriztapena Kdet-ean zein izenean ager daitekeela argudiatzea beharrezkoa dela defendatzen dut (Giannakidou-ri (2004) jarraituz) hizkuntzaz hizkuntzako datuen berri eman ahal izateko (ikus 3. atalean analisi honen alde egiten duten euskarako datuak). Are gehiago, hizkuntza desberdinetako datuek testuinguru aldagaia (agerian ala ezkutuan) normalean izenean agertuko dela adierazten dute; murriztapena Kdet-ean horretarako ebidentzia (adb. Daren presentzia) baldin badago defendatuko da.

\subsection{Dominioaren murriztapena izenean}

Matthewson-en proposamenaren kontra, Giannakidou-k (2004) st'át'imcets-eko (eta DS-a Kdet pean txertatzen duten hizkuntzetako) datuek, Kdet-arekin konbinatu behar den izenak aurretik testuinguruak murriztua izan behar duela adierazten dutela dio. Giannakidou-k egin beharreko oinarrizko asuntzioak hauek dira: (i) determinatzaile definituak predikatiboak izan daitezke (Partee 1987), (ii) testuinguru-multzoak denota ditzakete (Westerståhl 1985).

\footnotetext{
${ }^{7} \mathrm{Ez}$ da hau hala ere semantikaren literaturan aurki daitekeen analisi bakarra (ikus Kratzer 2004, Carlson \& Storto agertzeko; see also Cappelen \& Lepore 2002, 2005).
} 
Horrela, st'át'imcets-en murriztapena ageriko sintaxian emango da D-aren bitartez (à la Stanley \& Szabó 2000, Stanley 2002). D-ak nabarmentasuna ${ }^{8}$ adieraziko $\mathrm{du} C$ testuinguru aldagaiaren funtzioa betez eta sorrera multzoa (generator set) testuinguruak zehaztua izango duen zenbatzaile orokortu bat sortuko du. Beste modu batetara esanda, D-a eta IS-aren konbinaketak testuinguruan nabarmena den multzo bat sortuko du. Analisi honek azal dezake (i) st'át'imcets-eko DS-en irakurketa definitua, esistentzialki mailarik altuenean itxiak behar duten hautatze funtzioaren beharrik gabe (pace Matthewson 1999), (ii) st'át'imcets-eko definitu/indefinitu bereizketarik eza: hizkuntza honetako DS guztiak testuinguruak murriztuak izango dira testuinguruak zehaztutako sorrera multzo bakarra izango dutelarik, ondorioz, st'át'imcets-eko DS-ak erreferentzialak izango dira eta besarkadurarik zabalena izango dute beti.

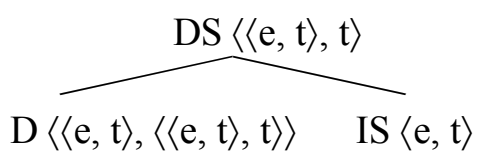

Behin (16)-ko konbinaketa lortuta, Partee-ren (1987) tipo-aldaketak $\langle\langle e, t\rangle, t\rangle$ tipoko ZO-a predikatu tipora $\langle\mathrm{e}, \mathrm{t}\rangle$ aldatzen du BE operatzailearen ${ }^{9}$ bitartez. Tipoaldatzaileak elementu sintaktikoak direla onartuz, st'át'imcets hizkuntzan, BE tipoaldatzailea ezkutukoa izango da eta partitiboaren funtzioa beteko du (ikus (17)). Azalpen honek, st'át'imcets-eko datuak azaltzeko gaitasuna izateaz gain, ZO-en analisi estandarra mantentzea baimentzen digu: hizkuntza honetan KdetS-ak egitura partitiboak izango dira.

(17a) [tákem i $\varnothing$ smelhmúlhats-a] [guzti D.pl (-tik) emakume(pl)-D] 'emakume guztiak'

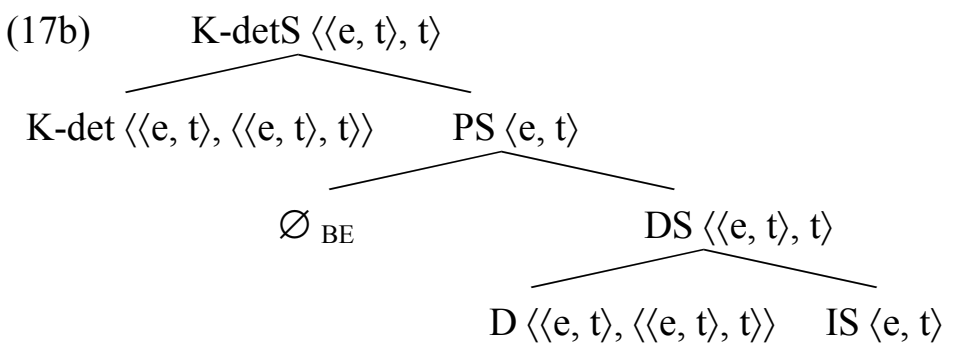

St'át'imcets-en ageriko partitiborik ez egotea analisi honen aldeko ebidentzia gehigarri bezala hartu behar da (ikus Matthewson 2001). Ageriko partitiboak dituzten hizkuntzetan (ingeleseko of adibidez) ezkutuko aldaketa blokatu egingo da, ageriko tipo-aldatzaileek ezkutuko tipo-aldaketa blokatzen dutelako (Chierchia 1998). Honek egokiro aurresaten du ageriko partitiboak dituzten hizkuntzetan ezingo dela DS bat Kdet-aren pean zuzenean lotu eta zenbatzaileen dominioaren murriztapena ageriko

\footnotetext{
${ }^{8}$ Ingeleseko saliency terminoaren kide gisa erabiltzen dut nabarmentasun.

${ }^{9}\langle\langle\mathrm{e}, \mathrm{t}\rangle, \mathrm{t}\rangle \rightarrow\langle\mathrm{e}, \mathrm{t}\rangle: \lambda \mathrm{P}_{\mathrm{et}, \mathrm{t}}[\lambda \mathrm{x}[\{\mathrm{x}\} \in \mathrm{P}]]:$ ZO bati aplikatzen zaio, bertan dauden elementu bakarreko multzoak hartu eta beren elementuak multzo bakar batean biltzen ditu.
} 
partitiboen bitartez egingo dela. Onarpen honek berebiziko garrantzia du artikulu honetan egingo den proposamenerako.

\subsection{Dominioaren murriztapena Kdet-ean}

Izena murrizteko aukeraz aparte, dominioaren murriztapena Kdet-ean gauza daitekeela ere onartu behar da von Fintel (1994) eta Martí-n (2003) (pace Stanley \& Szabó 2000, Stanley 2002) egiten den proposamena bermatuz. Hauxe da hain zuzen ere grekerako $o$ kathe edo st'át'imcets-eko $i$ zí7zeg'- $a$ elementuarekin gertatzen dena. Euskarako datuak 3.2.1 atalean ikus daitezke.

(18a) O kathe fititis det.sg bakoitz ikasle

$[\mathrm{D}[$ K-det $]](=17 \mathrm{~b})$ 'ikasle bakoitza'

(18b) [K-dets $\mathrm{O}_{\mathrm{D}}+$ kathe $_{\mathrm{K}-\operatorname{det}}[$ [S fititis $\left.\mathrm{I}]\right]$

(18c) o kathe fititis $=[$ kathe (C) $]$ (fititis)

'ikasle bakoitza'

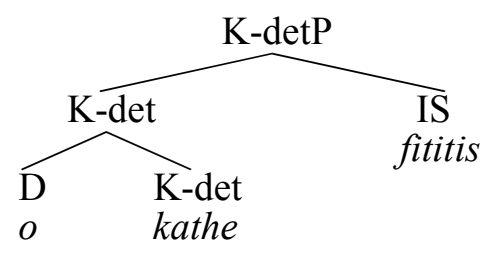

(18a)-k o kathe Kdet konplexu bat dela ematen du aditzera. (18d)-n adierazten den bezala, D-a Kdet-ari eransten zaio $C$ aldagaia edukiko duen eta testuinguruak murriztua izango den Kdet konplexu bat sortuz.

Determinatzaile definitu gehiagorik ez da onartuko dominioaren murriztapena Kdet-ean gertatzen denean, murriztapena jadanik gauzatu denaren erakusle.

$$
\begin{aligned}
& \text { *o kathe o fititis } \\
& \text { D.sg bakoitz D.sg ikasle(sg) } \\
& \text { lit.: 'ikasle-a bakoitz-a' }
\end{aligned}
$$

\subsection{Azpiatalaren laburpena}

Atal honetan zenbatzaileen dominioaren murriztapena izenean zein Kdet-ean gerta daitekeela erakutsi da (Giannakidou-k (2004) defendatzen duen moduan).

Ikusi dugun bezala, hizkuntza naturaletako kuantifikazioa azaltzen saiatzen diren bi analisi alternatibo daude: kuantifikazioaren analisi estandarra (Giannakidouren berrikuntzak jarraituz) eta Matthewson-ek proposatutako analisi alternatiboa. Jarraian, euskararen kuantifikazioari begiratuz ekingo diot eztabaida honi; hasteko euskarazko zenbatzaileen propietateak ikertuko ditut, propietate hauek dominioaren murriztatzailea izenean zein Kdet-ean ager daitekeela erakusten dutela azalduko dudalarik. Beraz, euskal kuantifikazio sistemak Giannakidou-ren proposamena bermatzen duela erakustera dator lan hau. 


\section{Euskal zenbatzaileen propietateak eta kuantifikazioaren teoria hizkuntza naturaletan}

\subsection{Euskal zenbatzaileen sailkapena}

Zenbatzaileen oinarrizko hiru propietatetan arreta jarriz hasiko naiz: (i) euskal determinatzaile definituarekin agertzeko aukera, (ii) esaldi esistentzialetan agertzeko aukera, eta (iii) aurresuposizionalak izateko aukera. ${ }^{10}$

\subsubsection{Determinatzaile definituarekin agertzeko aukera}

Euskal espresio kuantifikazionalen artean bada desberdintasun erabakigarri bat: zenbatzaile batzuk determinatzaile definituarekin agertu behar dute nahi eta nahi ez (20)-ko eta (21)-ko etsenpluek erakusten duten moduan.

(20a) [Ikasle guzti-ak] berandu etorri ziren.

(20b) $*$ [Ikasle guzti] berandu etorri ziren.

(21a) [Ikasle bakoitz-ak] goxoki bat jan zuen.

(21b) *[Ikasle bakoitz] goxoki bat jan zuen.

Beste euskal zenbatzaile batzuk berriz ezin daitezke determinatzaile definituarekin agertu, hau izenean edo zenbatzailean agertzen den axola gabe.

(22a) [Zenbait politikari] berandu iritsi ziren.

(22b) $*[$ Zenbait(-ak) politikari(-ak)] berandu iritsi ziren.

(23a) [Politikari asko] berandu iritsi ziren.

(23b) $*[$ Politikari(-ak) asko(-ak)] berandu iritsi ziren.

\subsubsection{Esaldi esistentzialak}

Determinatzaile definituarekin derrigorrean agertu behar duten zenbatzaileak ezin daitezke esaldi esistentzialetan agertu, (24a)-n ikus daitekeen moduan.

(24a) *Badira zientzilari guzti-ak/bakoitz-a laborategi honetan.

(24b) Badira zientzilari batzu(e)k/asko laborategi honetan.

\subsubsection{Aurresuposizionaltasuna}

Determinatzaile definituarekin konbinatzen diren zenbatzaileak aurresuposizionalak dira, hau da, konbinatzen diren IS-ak denotatzen duen multzoa multzo ez-huts eta nabarmena dela aurresuposatzen dute. (25)-n, akats-en multzoa aurresuposatua dago beraz.

\footnotetext{
${ }^{10}$ Ikus Etxeberria $(2002,2004,2005)$ propietate hauen analisi zabalago batentzat.
} 
(25a) Akats guzti-ak aurkitzen badituzu, goxoki bat emango dizut.

(25b) Ikasle bakoitz-ak liburu bat irakurtzen badu, goxoki bat emango diot. ${ }^{11}$

Determinatzaile definituarekin agertzen diren zenbatzaileekin gertatzen denarekin aurkakotasunean, determinatzaile definituarekin agertzen ez diren zenbatzaileek ez dute IS-ak denotatutako multzoa aurresuposatzen, hau da, (26)-n, akats-en multzoa hutsa izan daiteke.

(26a) Akats asko aurkitzen badituzu, goxoki bat emango dizut.

(26b) Akats batzu(e)k aurkitzen badituzu, goxoki bat emango dizut.

Propietate hauetan oinarrituz, euskal zenbatzaileak jarraian azaltzen den moduan sailka daitezke ( $c f$. Etxeberria 2002b, 2005):

(27)

Zenbatzaile sendoak: guzti, den, gehien, bakoitz. ${ }^{12}$

Zenbatzaile ahulak: batzu(e)k, zenbait, hainbat, ${ }^{13}$ asko, gutxi, ugari, numeralak, numerala baino gehiago, numerala baino gutxiago, etabar.

Beste hizkuntza batzuetan gertatzen den patroi bati jarraiki, (27)-n ahul bezala sailkatu diren zenbatzaileek irakurketa proportzional bat ere jaso dezakete. Horretarako, D-arekin eta ageriko -tik forma partitiboarekin agertu behar dute.

(28) [Ikasle-etatik gutxi] berandu iritsi ziren.

(29) [Ikasle-etatik asko] berandu iritsi ziren.

(30) [Ikasle-etatik batzu(e)k] berandu iritsi ziren.

Zenbatzaile hauek (eratorritako zenbatzaile sendoak) proportzionalak dira nahitaez eta ikasleetatik-ek testuinguruan nabarmena den ikasle multzoa denotatzen du (28, 29, 30)-n ( $c f$. Ladusaw 1982).

Egitura partitibo hauek lexikoki zenbatzaile sendoak direnen portaera berbera erakusten dute bai esaldi esistentzialetan, non ez-gramatikalak diren ((31) etsenplua), baita aurresuposizionaltasunari dagokionean ere, IS-ak denotatzen duen multzoa

\footnotetext{
${ }^{11}$ Beraren propietate banatzaileak medio, bakoitz egitura sintaktikoan bera baino barrenerago dagoen elementuren baten gaineko banaketa egin dezakenean bakarrik da gramatikala (cf. Etxeberria 2002a).

${ }^{12}$ Bada zenbatzaile unibertsal bezala tratatu izan den beste elementu bat: oro (cf. Euskaltzaindia 1993, Artiagoitia 2003). Elementu hau ez da lan honetan tratatuko. Ikus Etxeberria (2005).

${ }^{13}$ Batzu(e)k, zenbait, eta hainbat zenbatzaile ahulek irakurketa bera dute itxura batean. Hala ere, bada hiruen artean desberdintasun sotil bat: batzu(e)k bi kidez osatutako multzo bati erreferentzia egiteko erabili daitekeen bitartean, zenbait, eta hainbat-ek multzo handiago bati egiten diote erreferentzia.

(i) Lagun batzu(e)k etorri dira, Mikel eta Jon hain zuzen ere.

(ii) $\quad *$ ? Zenbait/Hainbat lagun etorri dira, Mikel eta Jon hain zuzen ere.
} 
aurresuposatzen dute multzo ez huts bati erreferentzia eginez, (32) etsenpluan erakusten den bezala.

(31a) *Badira zientzilari-etatik zenbait laborategi honetan.

(31b) *Badira zientzilari-etatik asko laborategi honetan.

(32a) Akats-etatik zenbait aurkitzen badituzu, 5 euro lortuko dituzu.

(32b) Akats-etatik asko aurkitzen badituzu, 5 euro lortuko dituzu.

Behin euskal espresio kuantifikazionalak sailkatuta, hurrengo atala euskararen sistema kuantifikazionalak kuantifikazioaren teori orokorrari egiten dion ekarria ikustera eskainiko da.

\subsection{Kuantifikazioaren teoria euskararen argitan}

Aurreko azpiatalean aurkeztutako euskarako datuak dominioaren murriztatzailea izenean zein Kdet-ean ager daitekeela erakustera datoz. Datu hauek hurrengo ondorioak bermatzen dituzte: (i) KdetS barneko D-ak dominioaren murriztatzailearen papera betetzen $\mathrm{du},{ }^{14}$ (ii) hizkuntzaz hizkuntzako kuantifikazioaren propietateak azaltzeko beharrezkoa da dominuaren murriztatzailea Kdet-ean edo izenean (egitura partitiboen bidez) agertu daitekeela onartzea, eta (iii) ZO-en analisi estandarrak hizkuntzaz hizkuntzako kuantifikazio azaltzeko gaitasuna du.

\subsubsection{Euskara eta dominioaren murriztapea Kdet-ean: Lexikoki zenbatzaile sendoak}

Grekera, ingelesa edo espainolez ez bezala, euskarako lexikoki zenbatzaile sendoak (guzti, den, gehien, bakoitz) zuzenean determinatzaile definituarekin osatzen dira hitzurrenkera posible bakar moduan [IS [K-det D]] emanez.

Horrela, Giannakidou-ren proposamenarekin adostasunean, lexikoki sendoak diren euskal zenbatzaileen egitura sintaktikotzat (33a)-n eskeintzen den hau proposatzen dut.

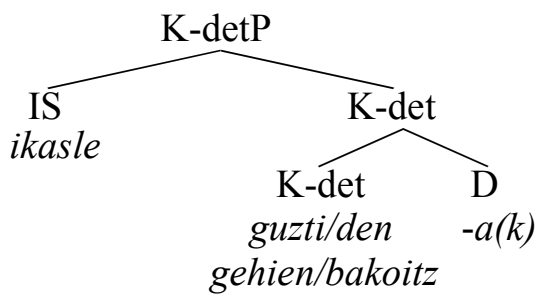

(33b) ikasle guztiak $=($ ikasle $)$ [guzti $(\mathrm{C})]$

(33c) $[$ guzti] $]=\lambda \mathrm{P} \lambda \mathrm{C} \lambda \mathrm{Q} \cdot\{\mathrm{x}: \mathrm{C}(\mathrm{x})=1 \& \mathrm{P}(\mathrm{x})=1\} \subseteq\{\mathrm{x}: \mathrm{Q}(\mathrm{x})=1\}$

(33d) $[[-a k]=\lambda x . x$ indibiduo isil bat $d a$

\footnotetext{
14 Euskal determinatzaile definitua testuinguru aldagaia izan daitekeenaren ideia euskarako $-a$ historikoki erakusletik eratorria izatearekin lotu daiteke (cf. Azkarate \& Altuna 2001), erakusleak testuinguruari hertsiki lotuak dauden elementuak baitira: hura / (h)a $\rightarrow-\mathrm{a}$
} 
Izan ere, euskarako lexikoki zenbatzaile sendoek Kdet-a eta D-a adjuntzio prozedura baten bitartez (edo eta D-a Kdet-ean inkorporatuaz) elkarrekin konposatzen direla ematen dute aditzera. Ondorioz, determinatzaile definituaren bitartez gauzatutako dominioaren murriztapenak $C$ aldagaia edukiko duen eta testuinguruak murriztua izango den Kdet konplexu bat sortzen du. Beraz, artikulu honen proposamena euskal lexikoki zenbatzaile sendoek hiru argumentu hartzen dituztela da, (33c)-n adierazten denaren moduan.

Beste analisi alternatibo bat ere proposa liteke, non euskarako lexikoki zenbatzaile sendoek KdetS baten ordez ((33a)-n azaltzen den bezala), (34)-ko egitura luketen DS-ak sortuko lituzketen.

(34)

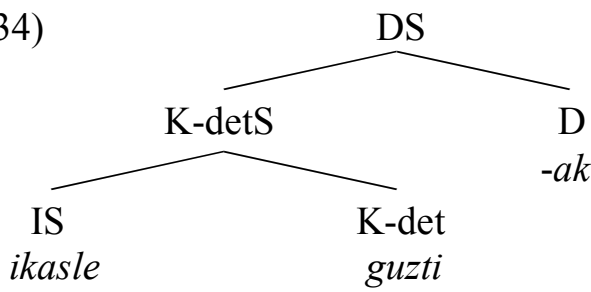

Onar dezagun, eztabaidarako soilik bada ere, (34)-ko egitura dela benetan zuzena den egitura. Gauzak horrela balira, posible izan beharko luke bi KdetS (hau da, bi [IS+Kdet] sekuentzia (34)-n) D bakar baten pean elkartzea, bi IS edo bi Adjektibo Sintagma (AdjS) elkartu daitezkeen modu berdinean.

IS elkarketa

(35a) [DS [IS Ikasle] eta [Is irakasle]-ak] azterketa garaian daude.

AdjS elkarketa

(35b) Maiak [DS [Adjs zaldi haundi] eta [AdjS elefante txiki]-ak] ikusi ditu.

Dena den, eta analisi alternatibo honek aurresango lukeenaren kontra, hurrengo esaldiak erabat ez-gramatikalak dira euskaraz.

(36a) *[[Ikasle gehien] eta [irakasle guzti]-ak] goiz iritsi ziren.

(36b) $*[[$ Neska bakoitz] eta [mutil guzti]-ek] sari bat irabazi zuten.

Horrela bada, esaldi hauek artikulu honetan proposatzen ari naizen analisiak aurresaten duen bezala, zera erakustera datoz: (i) euskarako lexikoki zenbatzaile sendoek KdetS-ak sortzen dituztela eta ez determinatzaile definitua buru dukeketen DS-ak, (ii) euskal determinatzaile definitua (sintagma kuantifikazionaletan behinik behin) Kdet-arekin batera konposatzen den testuinguru aldagaiaren funtzioa ari dela betetzen, bere eginbeharra kuantifikazioaren dominioa murriztearena delarik.

Kontestualizazioa Kdet-aren mailan gauzatzen denean (euskarako lexikoki zenbatzaile sendoekin gertatzen den moduan), beste determinatzaile definitu bat gehitzeak ez-gramatikaltasuna sortzen du tipoen ez-adostasun baten ondorioz. Izan 
ere, Kdet-ak, zenbatzaile orokortuen analisi estandarrak proposatzen duenaren kontra, $e$ tipoko osagarri bat jasoko luke $\langle\mathrm{e}, \mathrm{t}\rangle$ tipoko osagarri baten ordez.

(37a) *ikasle-ak guzti-ak

(37b) *ikasle-ak den-ak

(37c) *ikasle-ak gehien-ak

(37d) *ikasle-a bakoitz-a

Ohar gaitezen, ageriko forma partitiboak ere egitura ez-gramatikal bat sortarazten duela. Ez-gramatikaltasun hau dena den ez da espero izatekoa, egitura partitiboak ez baitu tipo ez-adostasunik sortzen (37)-ko etsenpluan gertatzen denaren kontra. Beste modu batetara esanda, ikasleetatik egitura partitiboak tipo zuzeneko osagarria $(\langle\mathrm{e}, \mathrm{t}\rangle$ tipoko osagarria) sortzen baitu Kdet-ak osagarri horren gainean kuantifikatu dezan; hala eta guztiz ere, (38)-ko etsenpluak ez dira gramatikalak.

(38a) *ikasle-etatik guzti-ak

(38b) *ikasle-etatik den-ak

(38c) ??ikasle-etatik gehien-ak

(38d) *ikasle-etatik bakoitz-a

Orain arteko datuak ikusita, testuinguru-murriztapena behin baino gehiagotan burutzeak ez duela tipo ez-adostasunik sortzen ohartu gara. Esaldi hauek ezgramatikalak izatearen arrazoia (lan honetan proposatzen denak aurrikusten duen moduan) dominioaren murriztapena dagoeneko gauzatua dagoela da zenbatzaile sendoarekin batera osatzen den D-aren bitartez. Testuinguru-murriztapena behin baino gehiagotan ezin gertatu izatearen arrazoia erredundantzi kasu bat izango da: zer esannahi edukiko luke testuinguru-murriztapena behin baino gehiagotan gauzatzeak? Ez askorik, testuinguru-murriztapenak ez baitu inolako esanahi deskriptiborik gehitzen, adjektiboek edo beste modifikatzaile batzuk egiten dutenaren kontra, zeintzuek erabilera bakoitzean esanahia gehitzen baitute eta IS-aren dominioa modu informatibo batean murrizten baitute. Erreparatu ezazue honi dagokionean, izen bat adjektibo berberarekin modifikatzea ere erredundantea dela esanahi desberdin bat sortzen ez dugun bitartean:

(39) Liburu garesti garesti bat

Etsenplu honetan, adjektiboetako batek bakarrik jokatzen du murriztatzailearen papera. Bestea "oso" bezalako graduzko modifikatzaile batean moduan interpretatzen $\mathrm{da}$, ondorengoa bezalako esanahi bat sorraraziz: liburu oso garesti bat. Ikus daitekeenez modifikatzaile berdin-berdinen erreduplikazioa galarazia dago egoera normaletan ere; ondorio naturala da beraz portaera berdina espero izatea testuingurumurriztapenaren fenomenoan ere. Gauza da, testuinguruaren murriztapena bi aldiz gauzatzeak ez-gramatikaltasuna ekartzen duela D-ak esanahi lexiko bakarra duelako eskura, (39)-ko adjektiboak ez bezala.

Artikulu honek (ikus baita ere Etxeberria 2005) D-ak testuingurmurriztatzailearen papera betetzen duenean modifikatzaile baten moduan portatzen dela defendatzen du (ikus 2.1. azpiatala); baina modifikazio honek, esanahi 
deskriptiboa gehitzen duten adjektibo edo beste modifikatzaileekin aurkakotasunean, ezin da behin baino gehiagotan erabili (40b)-ko ez-gramatikaltasunak argi eta garbi erakusten duen moduan.

(40a) Jonek txakur polit polit guzti-ak erosi zituen.

(40b) *Jonek txakur polit polit-etatik guzti-ak erosi zituen.

(40a) etsenpluan adjektiboetatik bakar bat interpretatzen da murriztatzaile gisa, bestea (lehen esan bezala) "oso" esan nahi duen graduzko modifikatzaile batean moduan interpretatzen da. Artikulu honetan planteatzen den proposamenari jarraiki (ikus baita ere Etxeberria 2005), testuinguru-murriztapena determinatzaile definituaren bitartez gauzatuko da. D-ak (edo egitura partitiboak) $C$ testuinguru-multzoaz aparte esanahi deskriptiborik ematen ez duenez, behin baino ezingo da erabili erredundantziarik sortuko ez badu, eta honen ondorio da (40b) etsenpluaren ikus dezakegun ezgramatikaltasuna.

Ohar gaitezen (38)-ko egiturak gramatikalak bihurtzen direla ikasleetatik partitiboa eta lexikoki zenbatzaile sendoak (guzti, den, gehien, bakoitz) tartean eten batekin ahoskatzen ditugunean, h.d. koma batez bananduak adibidez, (41b-c) etsenpluetan erakusten den bezala.

(41a) *Ikasleetatik guztiak berandu iritsi ziren.

(41b) Ikasleetatik, guztiak berandu iritsi ziren.

(41c) Ikasleetatik, berandu iritsi ziren guztiak.

Aitzitik, (41b-c)-ko eta (38)-ko egiturak berdin berdinak direnik ezin daiteke esan: eten batekin ahoskatzean, (41b)-n bezala, gramatikalak izateaz gain, zenbatzaileak zenbatzaile lerrakor bezala porta daitezke (41c)-n erakusten den bezala; etenik gabe ahoskatzen ditugunean ostera, etsenpluak erabat ez-gramatikalak dira (41a)-n argiro ikus daitekeenez.

(41)-eko etsenpluek aditzera ematen dutena hain zuzen ere egitura desberdinez ari garela da:

- (41a) eta (38)-ko zenbatzaileak benetako zenbatzaileak dira eta haien pare portatzen dira (lan honek aurresango lukeen bezala): testuinguru-murriztapena behin Kdet-ean gauzatuta ez dute izenaren gaineko murriztapen gehiagorik onartzen.

- (41b) eta (41c)-ko etsenpluetan berriz, partitiboaren ezkerreranzko dislokazio bat gertatzen dela ematen du eta ondorioz elementuek ez dute osagai bakar bat osatzen.

Bestalde, lan honetan proposatzen den analisiak Matthewson-en (2001) proposamenak euskarako izenei aplikatzean izango lukeen arazo bat sahiesten du. Izan ere, euskarako determinatzaile definituak $(-a /-a k)$ ez ditu $e$ tipoko elementuak bakarrik sortzen, eta tipo kuantifikazionala edo predikatiboan ere azaldu daiteke, esperokoa den bezala (ikus Etxeberria 2005). 
(42) Kuantifikazionala: $\langle\langle e, t\rangle, t\rangle$

Irakasle guztiak eta ikasle-a goiz iritsi dira.

(43) Predikatiboa: $\langle\mathrm{e}, \mathrm{t}\rangle$

Esther bizkaitarr-a da.

Orain arte, Kdet-ean bertan ere testuinguru-murriztatzailea ager daitekeela ikusi ahal izan dugu; euskarak espresio nominaletan murriztapenik izan ote dezakeen da orain sortzen zaigun galdera. Helburu horrekin, hurrengo azpiatalak eratorritako zenbatzaile sendo-etan jartzen du arreta, zeintzuek bigarren aukera honen (izena murriztearena) aldeko ebidentzia erakusten baitute.

\subsubsection{Euskara eta dominioaren murriztapena izenean: Eratorritako zenbatzaile sendoak}

Lexikoki sendoak diren zenbatzaileekin gertatzen denarekin aurkakotasunean, irakurketa proportzionala jasotzen duten euskarako eratorritako zenbatzaile sendoek, derrigorrean egitura partitiboarekin agertu behar dute. Ingelesez, grekeraz edo espainolez (eta beste hainbat hizkuntzetan) gertatzen denaren moduan, euskarako izenaren gaineko murriztapena agerian gertatzen da D-a eta egitura partitiboaren presentziarekin.

(44) [Ikasle-etatik gutxi] berandu iritsi ziren.

(45) [Ikasle-etatik asko] berandu iritsi ziren.

(46) [Ikasle-etatik batzu(e)k] berandu iritsi ziren.

Euskaraz, ageriko forma partitiboa den -etatik (zenbatzaile sendoak sortzen dituena), -eta pluraleko markatzailearekin (ohiko pluraleko markatzaile $-k$ da) ${ }^{15}$ asimilazio prozesu baten ondorioz ikusten ez den $-a$ determinatzaile definitua eta ablatibo markatzailea den -tik postposizioaren konbinaketatik sortzen da. ${ }^{16}$ Euskaraz, kasua atzizki bidez markatzen da eta paradigma indeterminatu eta determinatua morfologikoki desberdindu daitezke.

\begin{tabular}{|l|c|c|c|}
\hline & indeterminatua & determinatu sg. & determinatu pl. \\
\hline Ergatiboa & etxe- $k$ & etxe- $a k$ & etxe-ek \\
\hline Ablatiboa & etxe-ta-tik & etxe-tik & etxe-eta-tik \\
\hline
\end{tabular}

Determinatzaile definitua -etatik formaren barnean dagoela ondoren azaltzen den moduan ziurta daiteke: Hausnartzen ari garen egitura partitiboek testuinguruan nabarmenak diren etxe (kasu honetan) guztien multzoa denotatzen dute eta egitura hauetan determinatzaile definitua beharrezkoa dela argudiatzen ari gara. Itxura batean, posible izan beharko luke eratorritako zenbatzaile sendo bat ablatiboaren

\footnotetext{
${ }^{15}$ Ikus Azkarate \& Altuna (2001) -eta plural markatzailearen analisi historiko batentzat

${ }^{16}$ Ikus Eguzkitza (1997).
} 
forma indeterminatua erabiliz eratzea, baina (48a)-ko etsenpluak erakusten duen bezala, ezinezkoa da horrelako egitura bat eratzea.

(48a) *etxe-ta-tik asko

(48b) etxe-eta-tik asko

Horrela bada, -eta numeroa eta definitutasuna morfema bakar batean markatzen dituen morfema konposatu baten moduan ulertu behar da.

(49)-k erakusten duen bezala, (44), (45) eta (46)-ko adibideetan erabiltzen den egitura partitiboa ohiko egitura partitibo bat da, non lehenengo IS eta D-aren arteko konbinaketak $e$ tipoko entitate-denotatzaile bat sortzen duen. Euskarako -tik atzizkia $e$ tipoko osagarri bat hartu eta zenbatzaileak onar dezakeen $\langle e, t\rangle$ tipoko elementu bat sortzen duen ageriko tipo-aldatzailea izango da. Azken konbinaketa honetatik, ohiko $\langle\langle\mathrm{e}, \mathrm{t}\rangle, \mathrm{t}\rangle$ tipoko zenbatzaile orokortu bat jasotzen dugu. Beraz, ikasleetatik bezalako zerbait ikasle izenak denotatzen duen tipo bereko objektu bat izango da, baina ikasle guztien multzoa denotatu beharrean, testuinguruan nabarmenak diren ikasle guztien multzoa denotatuko du (Ladusaw 1982).

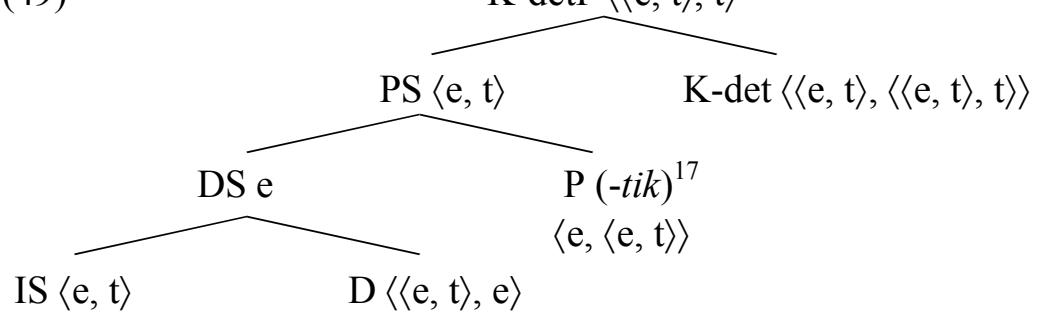

Euskarako lexikoki zenbatzaile sendoekin gertatzen zen bezalaxe, eta eratorritako zenbatzaile sendoak ere testuinguru-murriztapena jasotzen dutela (egitura partitiboaren bitartez) aurresanda, definitu gehiagorik ez da onartuko. ${ }^{18}$

\footnotetext{
${ }^{17}$ Russell-i (1905) jarraituz (ikus Neale 1990) D-a testuinguruak zehaztutako sorrera multzoa dukeen zenbatzaile unibertsal bezala tratatu liteke. Kasu horretan, [IS+D] sekuentziak ZO bat sortuko luke eta -tik partitiboak burutuko lukeen funtzioa BE tipo aldatzailearena litzateke, zeinak zenbatzailearentzat tipo egokiko osagarri bat sortuko lukeen.

${ }^{18}$ Oso interesgarria da espainoleko la mayoría de DS-rekin gertatzen dena; izan ere, beharrezkoa du bai partitiboaren bai D-aren presentzia gramatikala izan behar bada. Honek ez luke honela izan behar testuinguru-murriztapena behin bakarrik gauza badaiteke.Gainera, propietate honek la mayoría de DS espainoleko gainerako zenbatzaile sendoengandik bereitzen du (h.d. cada chico 'lit.: bakoitz mutil', todo chico 'lit.: guzti mutil', muchos de los chicos 'lit.: asko -tik D mutil').

(i) La mayoría de los estudiantes suspendieron el examen.

D.sg gehiengo -tik D.pl ikasle.pl ez gainditu D.sg azterketa

'Ikasleen gehiengoak azterketa ez zuten gainditu.'

Antzeko zerbait gertatzen da grekerako i perissoteri elementuarekin (Giannakidou 2004: 13) "zeinak D KdetS urrenkera erakusten duen eta aldi berean (hautazko) osagarri definitu bat hartu dezakeen”. Giannakidou-k definituaren erreduplikazioaz baliatuz konpontzen du arazoa. Irtenbide hau hala ere ezin daiteke espainoleko kasuan erabili lehenengo D-a ez baita bigarrengo D-aren (partitibo barnekoa) menpekoa eta desberdinak ere izan baitaitezke (ikus (i) etsenplua). Gertatzen dena zera da itxura batean: espainoleko mayoría izen bat da eta la mayoría de DS-ko lehenengo D-a arrazoi sintaktikoengatik soilik agertzen da, espainolez izen bilutsiak ez baitira onartzen.
} 
(50a) *Ikasleetatik asko-ak

(50b) *Ikasleetatik gutxi-ak

(50c) *Ikasleetatik zenbait-ak

Bestalde, st'át'imcets hizkuntzarentzat proposatu den egituraren (ikus (17) etsenplua) eta euskarako eratorritako zenbatzaile sendoen egituraren artean bada ageriko desberdintasun bat. St'át'imcets-ek ageriko egitura partitiborik ez duenez ezkutuko tipo-aldatzaile bat proposatu dugu Kdet-ak behar duen tipoko osagarri batekin konbina dadin. Ostera, euskarak badu ageriko forma partitibo bat (-tik) eta elementu honek testuinguruak murriztutako izenak ezkutuko tipo-aldaketa jasateko aukera sahiesten eta baztertzen du (51)-n argi eta garbi erakusten duen bezala.

(51a) *Ikasle-ak $\varnothing$ asko.

(51b) *Ikasle-ak $\varnothing$ gutxi.

(51c) *Ikasle-ak $\varnothing$ zenbait.

Beraz, zuzena dirudi ondorengoa ondorioztatzea: (i) euskarako zenbatzaileek argiro erakusten dute dominioaren murriztapena Kdet-ean zein izenean gauza daitekeela zenbatzaileak lexikoki sendoak ala eratorritako zenbatzaile sendoak direnaren arabera, ${ }^{19}$ (ii) testuinguru-murriztapena behin bakarrik gertatzen da: dominioaren murriztapena Kdet-ean gertatzen denean izena murriztuko luketen egitura partitiboak ezin daitezke erabili eta alderantziz, (iii) Zenbatzaile orokortuen analisi estandarra (Giannakidou-ren berrikuntzarekin) zuzena da (pace Matthewson 2001).

Aurreko atalak euskarako zenbatzaile sendoak derrigorrez determinatzaile definituarekin agertu behar dutela erakustera etorri da. Erabakigarriro, euskaraz, dominioaren murriztatzailea barneratzen duela proposatu dudan D-a erabat bateraezina da zenbatzaile (kardinal-)ahulekin. Propietate hau, zenbatzaile ahulak testuinguruak murriztugabeak direnaren ebidentzia gisa hartzen dut.

\subsection{Zenbatzaile ahulak eta murriztugabeko kuantifikazioa}

Aurretik aipatu dugun bezala, hizkuntza naturaletan ere bada murriztugabeko zenbatzaileentzat lekurik ( $c f$. Cooper 1996, von Fintel 1998). Honi dagokionez, euskarak ageriko sintaxian erakusten du testuinguruak murrizten dituen (D-aren bitartez) eta murrizten ez dituen zenbatzaileen arteko desberdintasuna. (22-23) etsenpluetan adierazi dudan bezala, (52-53)-n errepikatuak, euskarako zenbatzaile ahulak ezin daitezke $-a /-a k$ dominioaren murriztatzailearekin agertu, murriztatzailea non agertzen den axola gabe (izenean edo zenbatzaile ahulean bertan).

\footnotetext{
19 Lexikoki zenbatzaile sendoen eta eratorritako zenbatzaile sendoen arteko desberdintasunaren arrazoietako bat lexikoki sendoak diren zenbatzaileak historikoki adjektiboetatik eratorriak izatearekin lotu daiteke (cf. Trask 2003: 128), euskarako adjektiboak - $a$-ak determinatzaile definituarekin agertu behar baitute derrigorrean (ikus Etxeberria 2005). Egun, lexikoki sendoak diren zenbatzaileak ez dira adjektiboen pare portatzen eta ZO-ak denotatzen dituzte (ikus Etxeberria 2004, 2005). Eskerrak Joseba Lakarra-ri (k.p.) puntu honen gainean izandako eztabaidarengatik.
} 
(52a) [Zenbait politikari] berandu iritsi ziren.

(52b) $*[$ Zenbait(-ak) politikari(-ak)] berandu iritsi ziren.

(53a) [Politikari asko] berandu iritsi ziren.

(53b) $*[$ Politikari(-ak) asko(-ak)] berandu iritsi ziren.

Hizkuntza naturaletako zenbatzaileak testuinguruak murriztuak izan behar dutela kontutan izanda, zenbatzaile ahul hauek $\langle\mathrm{e}, \mathrm{t}\rangle$ tipo predikatiboan sortzen direla proposatuko dut, $\langle\langle\mathrm{e}, \mathrm{t}\rangle,\langle\langle\mathrm{e}, \mathrm{t}\rangle, \mathrm{t}\rangle\rangle$ tipo kuantifikazionalean sortu ordez. Honen ondorio izango da elementu hauek ez direla zenbatzailetzat hartu behar argudiatzea (cf. Milsark 1979, Partee 1988, van Geenhoven 1998, Landman 2002). Ohar gaitezen, zenbatzaile sendoekin gertatzen denarekin aurkakotasunean, elementu hauek posizio predikatiboetan ager daitezkeela; (54)-k erakusten duen bezala.

(54) Gonbidatuak [neska asko/batzu(e)k/gutxi] ziren.

(55) *Gonbidatuak [neska guzti-ak/den-ak/bakoitz-a] ziren.

(56) *Gonbidatuak [nesketatik asko/batzu(e)k/gutxi] ziren.

Beraz, asko bezalako zenbatzaile kardinal-ahul baten eta neska bezalako IS predikatu baten (zeina ohiko asuntzioak jarraituz $\langle\mathrm{e}, \mathrm{t}\rangle$ tipoko izango den baita ere) konbinaketa ebaketa (multzo teorian ulertzen den bezala) deritzon prozedura baten bitartez emango dela proposatzen dut ( $c f$. Landman 2002) emaitza bezala berriro ere $\langle\mathrm{e}, \mathrm{t}\rangle$ tipoko elementu bat emanez. Posizio predikatiboetan, modu honetan interpretatuko dira eta beren egitura (57)-n eskaintzen dena izango da.

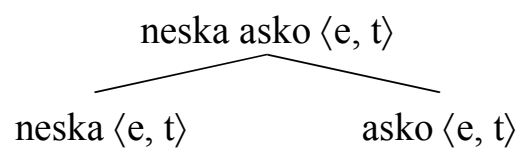

Are gehiago, zenbatzaile ahula determinatzaile definituarekin ez agertzearen arrazoia determinatzaile definitua baino beheragokoa den posizio sintaktiko baten sortzen direla da, hau da, zenbatzaile ahulak deituak izan direnak DS proiekzioaren azpitik sortzen dira egitura sintaktikoan. Honek sahiesten du hain zuzen ere zenbatzaile ahulak determinatzaileekin agertzeko aukera. Jarraian, zenbatzaile ahulen sorrera posizioa numero kategoriarekin erlazionatua dagoen Numero Sintagma (NumS) dela erakutsiko dut (ikus Ritter 1991, Vangsness 2001 beste askoren artean; ikus Artiagoitia 2003 euskari dagokionean). ${ }^{20}$

Proposamen honen ebidentzia gisa, zentra gaitezen euskarako determinatzaile definituaren jokabidean. Euskal determinatzaile definitua ikertu duten ikerlarien esanetan (adb. Goenaga 1991, Euskaltzaindia 1993, Ticio 1996, Artiagoitia 1998, 2003, Rodriguez 2003, Trask 2003), elementu hau bi modutara burutu daiteke: $-a$

\footnotetext{
${ }^{20}$ Ikerlari askok proposatu eta defendatu dute (i) zenbatzaile sendo eta ahulen sorrera leku sintaktikoa desberdina dela eta (ii) zenbatzaile ahulek lor ditzaketen irakurketa desberdinak sintaktikoki adieraziak direla (ikus adb. Hudson 1989, Giusti 1991, Muromatsu 1998, eta Vangsness 2001).
} 
singularreko forman eta $-a k$ pluraleko forman. Ikerlari hauekin bat nator pluraleko forma $-a$ determinatzaile eta $-k$ pluraleko markaz osatua dagoela esatean. Baina, (itxuraz behintzat) ikerlari hauek guztiek $-a$ eta $-k$ posizio sintaktiko berean sortzen direla asumitu dute, hau da, DS-aren buruan, singularreko - $a$ sortu dela defendatu den posizio berdinean.

Artikulu honetan proposatu nahi den analisiak - $a$ determinatzaile definitua eta $-k$ pluraleko markatzailea posizio sintaktiko desberdinetan sortzen direla dio: $-k$ pluraleko markatzailea NumS-an sortzeko den bitartean, - $a$ determinatzaile definitua (ohikoa den bezala) DS-an sortzen dela defendatuko da.

Proposamen honen aldeko argudioetako bat eta juntaduraren bitartez sortzen diren egitura koordinatuetan ematen diren irakurketetan oinarritzen da. Ikusiko dugunez, NumS posizioa DS posizioaren gainetik dagoela onartuko bagenu egitura koordinatuetan ematen diren irakurketak azaltzeko arazoak edukiko genituzke. Har ditzagun bada etxe eta baserri izenak, ${ }^{21}$ eta ikus dezagun zer gertatzen eta juntadurarekin elkartzen ditugunean. ${ }^{22}$

(58) Aldi berean, etxe eta baserria da eraikin hori.

(58)-ko etsenpluan, determinatzaile definitu singularrak besarkadura zabala du koordinaziozko egitura guztiarengan (58')-n adierazten den bezala.

(58') [ [ etxe ] eta [ baserri ] ]-a

(59)-n, aurreko egiturari - $k$ pluraleko markatzailea gehitzen diogu.

(59) Etxe eta baserriak

Adibide honetan, etxeak zein baserriak bat baino gehiago izan behar dute nahi eta nahi ez, hau da, biek pluralak izan behar dute. (59)-ko etsenpluan etxe izen arruntarekin ez da inolako numero markatzailerik ageri (aurreko adibidean bezalaxe) eta itxura batean $-k$ pluraleko markatzaileak koordinazio guztiaren gaineko besarkadura hartzen du. Noski, hau ez da espero ez den zerbait, $-k$ pluraleko markatzailea - $a$ determinatzaile definituaren ondoren agertzen baita, eta euskaraz, buru bat eskubitarago agertzen denean beraren ezkerretara agertzen diren sintagmen gaineko besarkadura duela asumitzen baita normalean. Suposa dezagun (59)-ko koordinazioak ondoren erakusten den egitura daukala:

$\left(59^{\prime}\right) \quad[[$ [ etxe ] eta [ baserri ] -a ]-k ]

Alda dezagun etsenplua pixka bat eta gehitu diezaiogun determinatzaile definitu bat koordinazioko lehenengo izenarekin.

(60) Etxea eta baserriak

\footnotetext{
${ }^{21}$ Euskal izenek ez dute numero markarik eta determinatzailea proposatu izan da singulartasun eta pluraltasun markatzaile gisa. Cf. Goenaga 1991, Euskaltzaindia 1993, Ticio 1996, Artiagoitia 1998, 2003, Trask 2003, etabar.

${ }^{22}$ Eskerrak Ricardo Etxepare-ri (k.p.) puntu honen gainean izandako eztabaidengatik.
} 
Hemen ere, itxura batean behintzat, pluraleko numero markatzaileak koordinazio guztiaren gainetik izan beharko luke besarkadura, hau da, etxea eta baserria elementuen gainetik.

$\left(60^{\prime}\right) \quad[[[$ [ etxe $]-\mathrm{a}]$ eta $[[$ baserri $\left.]-\mathrm{a}]]-\mathrm{k}\right]$

Baina, (58)-ko etsenpluen jasotzen genuen irakurketarekin aurkakotasunean, egitura honetan (horrela espero behar ez genukeen arren (60')-ko adibide azuzena balitz) etxe bakar bati bakarrik egiten diogu erreferentzia.

Bestalde, numero markatzailea determinatzaile definituaren pean sortzen dela asumituko bagenu, jarraian erakusten den egitura (modu abstraktu batean) lortuko genuke.

\section{(61) $\quad[$ [ [ etxe ] Num ] -a ] eta $[$ [ [ baserri $]$ Num ] -a ]}

Adibide honetan daukaguna bi DS-en koordinazioa da. DS bakoitzak beraren numeroa izango du eta hauxe da koordinazioa behar den bezala interpretatzea baimenduko diguna: lehenengo izen arrunta singularra izango da (singularreko numero markatzaile hutsarekin $\varnothing$ ) bigarrengo izen arrunta plurala (pluraleko markatzailearekin $-k$ ) izango den bitartean. Honela, koordinazioa behar den bezala interpretatzeko gai izango gara: etxe bakar bat eta baserri bat baino gehiago. Azaleko azken hitzurrenkera lortzeko, Numero burua azken posiziora mugitu eta D buruari atxikitu beharrean gertatuko da.

(62b) Plural:

$$
\begin{array}{lll}
{[[[\text { etxe }] \varnothing]-\mathrm{a}] \varnothing} & \Rightarrow & \text { etxe-a } \\
{[[[\text { etxe }]-\mathrm{k}]-\mathrm{a}]-\mathrm{k}} & \Rightarrow & \text { etxe-a-k }
\end{array}
$$

Pluraleko $-k$ markatzailea (singularreko numero markatzaile hutsarekin batera) atzizki bat dela asumitzen dut, eta ondorioz fonologikoki zein kategorikoki beste kategoria baten menpe egongo da (klitikoekin aurkakotasunean, zeinak fonologikoki bakarrik baitaude beste elementuren baten menpe (ikus Zwicky 1977, 1985)), eta kategoria hau $\mathrm{D}^{\circ}$ burua izango da. Hau dela eta, pluraleko markatzailearen DS-aren azken posiziorainoko mugimendu hau morfologiari zor zaiola esan daiteke. Pluraleko markatzailea atzizki bat izateak zenbatzaile ahulak ere (proposatutakoaren arabera NumS-n sortzen direnak) DS-aren azken posiziora mugitu beharko luketeela asumitu behar izatea ekiditen du; zenbatzaile ahulak ez dira atzizkiak.

Gauzak horrela, zenbatzaile ahulek posizio predikatiboetan izango duten egitura sintaktikoa jarrain erakusten dena izango da. Egitura hau $\langle\mathrm{e}$, $\mathrm{t}\rangle$ tipo predikatibokoa izango da. ${ }^{23}$

\footnotetext{
${ }^{23}$ Buru-azken egitura bat onartzen ari naiz. Espezifikatzaile posizioa ezkerretara egongo da beti. Ikus beste zenbaiten artean Ortiz de Urbina (1989), Laka (1990), Elordieta (2001), edo Artiagoitia (2000).
} 


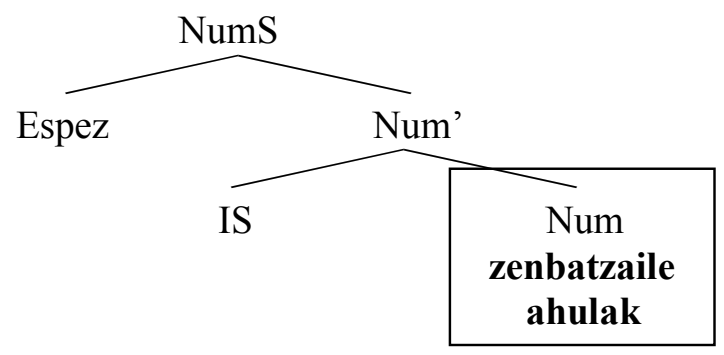

Dena den, interpretazio predikatiboa ez da zenbatzaile ahulek (ageriko egitura partitiborik gabe) lor dezaketen irakurketa bakarra eta argumentu posizioa ere bete dezakete elementu hauek. Posizio honetan $\langle\mathrm{e}, \mathrm{t}\rangle$ tipoko objektuak agertu ezin daitekeenez, $e$ entitate tipoko edo $\langle\langle\mathrm{e}, \mathrm{t}\rangle, \mathrm{t}\rangle$ kuantifikazio tipoko elementu bat beharrezkoa izango da beraz. Argumentu posizioan, zenbatzaile ahulek irakurketa kardinala edo irakurketa proportzionala lor dezakete (64)-ko etsenpluak adierazten duen bezala ( $c f$. Huettner 1984, Partee 1988)

(64) Ikasle askok goxokiak jan zituzten.

$\rightarrow$ KARDINALA: ikasle asko numero dagokionean

$\rightarrow$ PROPORTZIONAL: ikasleetatik asko

Irakurketa kardinala lortzeko zenbatzaile esistentzial isil bat erabiliko dugu. Zenbatzaile esistentzial $(\exists)$ hau $\langle\langle e, t\rangle,\langle e, t\rangle, t\rangle\rangle$ tipo kuantifikazionalekoa izango da eta $\langle\mathrm{e}, \mathrm{t}\rangle$ tipokoa den ikasle asko-rekin konbinatuta, egi-balioa emateko aditzarekin konbina daitekeen $\langle\langle e, t\rangle, t\rangle$ tipoko ohiko zenbatzaile orokortu bat sortuko du. Zenbatzaile esistentzial inplizitu hau Kdet-ean kokatuko da eta (64)-ko etsenpluko subjektu batentzat lortuko dugun forma logikoa (65)-ean adierazten dena izango da.

[ [ $\exists x[i \operatorname{ikasle}(x) \& \operatorname{asko}(x)]]$

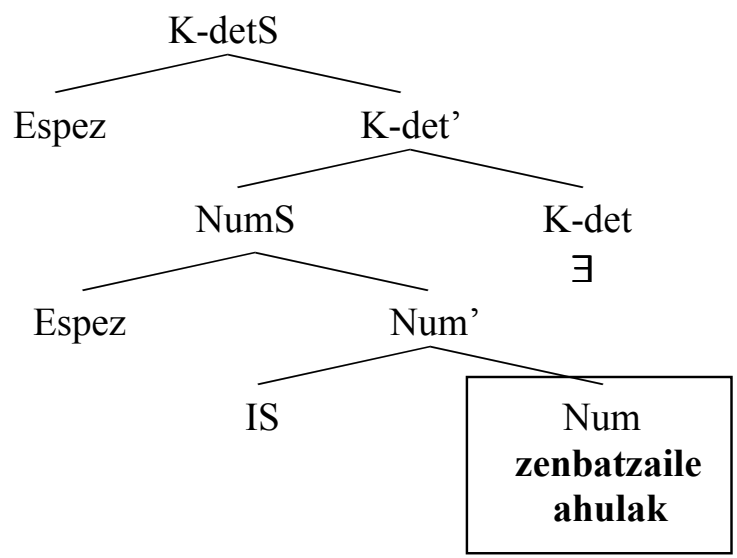

Ortiz de Urbina-k (1989) eta Laka-k (1990) ezkerraldeko periferiako proiekzioak (fokoa, ezeztapena, nz-buruak, etb.) buru-lehen direla argudiatzen dute; desberdintasun honek asimetria bat sortzen du euskararen sintaxian.

Bestalde, Haddican-ek (2001, 2004, 2005) euskara buru-lehen dela proposatzen du. 
Horrela bada, izen sintagma indefinituen irakurketa kardinalak (argumentu posizioan) interpretazio predikatiboetatik eratorriak izango dira zenbatzaile esistentzial isil batek bultzatutako tipo-igoera baten bitartez (ikus Landman 2002). Operazio honek $x$ indibiduoez eratutako multzo bat hartzu eta zenbatzaile orokortu bihurtzen du, hau da, $x$-ekin ebaketa ez-hutsa izango duten multzo guztien multzoa.

Irakurketa proportzionalerako berriz, Büring (1996) jarraituko dut, non partitibo isilaren fenomenoa ikuspuntu pragmatiko batetik hurreratzen den. Irakurketa kardinala eta proportzionala lexikoietik zehaztuta daudela dioen ikuspuntu semantikoarekin ( $c f$. Partee 1988, Diesing 1992, de Hoop 1992) aurkakotasunean, Büring-ek zenbatzaile ahulak ez direla anbiguoak proposatzen du: beren irakurketa proportzionala (eta ondorioz aurresuposizionala) Topiko/Foko/Aurreko Egitura (TFAE) (Topic/Focus/Background Structure (TFBS)) deritzonaren menpe dago; eta gauzak horrela ez da egongo ezkutuko egitura partitibo bat aldarrikatu beharrik ageriko partitibo bat ez dagoen kasuetan.

Hamblin (1973)/Karttunen (1979)-en tradizioan, galdera baten denotazioa beraren erantzun posibleak batzen dituen proposizioen multzo bat da. Rooth (1985, 1992) jarraituz, multzo honen izena Foko Balioa (Focus Value) deritzona da. Honela, zer edan zuen Aritzek? bezalako galdera batek Aritzek x edan zuen bezalako esaldiek adierazten duten proposizio guztien multzoa denotatuko du. Baiezko esaldi bat galdera inplizitu baten erantzuna balitz bezala ulertu daiteke beraz, testuinguruaren parte izatea bezala ere hartu daitekeena.

(66a) Aritzek GARAGARDOA edan zuen.

(66b) $[[$ Zer edan zuen Aritzek?] $]=\{[[$ Aritz ardoa edan zuen $]]$, [[Aritzek tea edan zuen $]$, [[Aritzek whiskya edan zuen $]]$, [[Aritz cognaca edan zuen]] ...\}

Orain, (67a)-ko esaldia, subjektuan Büring-ek topiko kontrastiboa deritzon azentua eta objektuan foko ertsiaren azentua dituena, (66a)-ko etsenplutik ondorengoan desberdintzen da: fokalizatutako garagardoa objektuaz gain, Aritz subjektua ere testuinguruan nabarmenak diren alternatibekin ordezkatuko beharko da ((67b)-n adierazia).

(67a) $[\text { ARITZEK }]_{\mathrm{T}}[\text { GARAGARDOA }]_{\mathrm{F}}$ edan zuen.

(67b) $[[$ Zeinek edan zuen zer?] $]=\{[$ Jonek garagardoa edan zuen $]]$, [[Jonek ardoa edan zuen $]] \ldots\},\{[[$ bi mutilek garagardoa edan zuten]], [[bi mutilek ardoa edan zuten $]] \ldots\},\{[[$ Maia eta Aritzek garagardoa edan zuten]], [[Maia eta Aritzek ardoa edan zuten]] ...\}

Büring-ek (1996) alternatiben analisi hau espresio kuantifikazionaletara zabaltzen du eta (68a) bezalako adibideek ere bi azentu mota dituztela argudiatzen du; azentu horietatik lehenengoa topiko kontrastiboa deritzon azentua izango da, eta ez foko azentu bat. Honelako esaldi batek ahalezko testuinguruez osatutako multzo baten berreraiketa bat bultzatzen du, batzuek beraren testuinguruko alternatiba nabarmenen ordezkapenetik lortzen dena hain zuzen ere, (68b)-n adierazten den bezala. 
(68a) Ikasle $[\mathrm{BATZU}(\mathrm{E}) \mathrm{K}]_{\mathrm{T}}[\mathrm{GARAGARDOA}]_{\mathrm{F}}$ edan zuten.

(68b) Zer edan zuten ikasle guztiek? Zer edan zuten bost ikaslek? Zer edan zuten ikasle gutxik? Zer edan zuten ikasle askok?

Aurreko ahalezko testuinguru hauetatik benetako Diskurtso-Gaia zein den ez dio axola, (68b)-ko alternatiba guztiek topiko posizioa bete lezaketen elementuak sorrarazten baitituzte, eta ondorioz, ikasle multzo baten esistentzia beti izango da aurresuposatua. Modu honetan, (68a)-ko esaldia entzutearekin batera -diskurtsoaren hasera bada ere- diskurtsoaren testuinguruak ikasle multzo batekin zerikusia izango duela badakigu. (68a)-n batzuek-ek lortzen duen irakurketa partitiboa, izena (baina ez zenbatzaile ahula) aurreko diskurtsoaren parte izatetik dator; beste modu batetara esanda, irakurketa partitibo/aurresuposizionala, esaldiak eskatzen duen testuingurua dela eta azaleratzen da

Modu honetako esaldi batekin diskurtsoaren haseran topo egiten dugunean "esaldiak berak eskaintzen digun edozein informazio posiblerekin testuinguru bat eraikitzen saiatzen gara; eta dugun informazio iturririk hoberena -lexikotik datozen aurresuposizioak aparte- aurretik aipatu dugun TFAE delakoa da” Büring (1996:19). ${ }^{24}$

Azpiatal honek zenbatzaile kardinal-ahulak testuinguruak murriztugabeak diren ideiaren aldeko argudioak azalaratu ditu. Euskarak, propietate hau ageriko sintaxian erakusten du, zenbatzaile sendoekin aurkakotasunean, zenbatzaile ahulek ez baitute determinatzaile definiturik onartzen, zeinak testuinguruko dominioaren murriztapena barneratzen duela defendatu den artikulu honetan.

\section{Ondorioak}

Artikulu honen ondorio teoriko garrantzitsuenak ondorengo puntuetan aurki daitezke:

(i) Hizkuntza naturaletako kuantifikazioa testuinguruak murriztua izan behar du ezkutuko edo ageriko testuinguruaren aldagaiekin (von Fintel 1994, 1998, Stanley \& Szabó 2000, Stanley 2002, Martí 2003); hizkuntzaz hizkuntzako kuantifikazioa azaltzeko beharrezkoa da dominuaren murriztatzailea Kdet-ean edo izenean agertu ahal izatea, eta hizkuntzak kuantifikazioaren dominioa agerian edo ezkutuan murrizten dutenaren arabera desberdintzen dira.

(ii) Euskarazko zenbatzaileen datuek argiro erakusten dute dominioaren murriztapena Kdet-ean (Westerståhl 1985, von Fintel 1994, Martí 2003) zein izenean (Stanley \& Szabó 2000, Stanley 2002) ager daitekeela. Batean edo bestean agertzea zenbatzaileak lexikoki sendoak ala eratorritakoko zenbatzaile sendoak (§3.2.2) izatearen ondorio izango da: Lexikoki sendoek D-a Kdet-arekin sortzearen aldeko ebidentzia erakusten dute; eratorritako sendoek bestalde, egitura partitiboak sortzen dituzte, eta ingelesez, grekeraz edo espainolez bezala izenaren murriztapena agerian gertatzen da egitura partitiboaren bitartez.

\footnotetext{
${ }^{24}$ Büring-en proposamena aurresuposizioaren egokitze deitu izan denarekin bat dator. Ikus Karttunen (1973), van der Sandt (1992).
} 
(iii) Kdet-S barneko determinatzaile definitua dominioaren murriztatzailetzat hartuta zenbatzaile orokortuen teoriak ez du berrikuspenik behar (Giannakidou 2004). Euskarako datuak ondorio honen aldeko berma dira.

(iv) Euskarak, zenbatzaile kardinal-ahulak (zenbatzaile sendoekin aurkakotasunean) testuinguruak murriztugabeak direla ageriko sintaxian erakusten du, ez baitute determinatzaile definiturik onartzen. Honela, zenbatzaile ahul hauek semantikoki $\langle\mathrm{e}, \mathrm{t}\rangle$ tipo predikatiboan (van Geenhoven 1998, Landman 2002), eta sintaktikoki NumS proiekzio funtzionalean sortzen direla defendatu da.

(v) Zenbatzaile ahulen irakurketa proportzionala, ageriko -etatik egitura partitiborik ez dagoenean, pragmatikaren bitartez azaldu da (Büring 1996). Ondorioz, irakurketa hau ez ezkutuko egitura partitibo baten ondorio izango (pace Partee 1988).

\section{Erreferentziak:}

Adams, N. 2005. Quantification and partitivity in Zulu. Eskuizkribua. University of Chicago.

Artiagoitia, X. 1998. "Determinatzaile sintagmaren hipotesia euskal gramatikan". Uztaro 27: 33-61.

Artiagoitia, X. 2000. Hatsarreak eta Parametroak Lantzen. Vitoria-Gasteiz: Arabako Foru Aldundia.

Artiagoitia, X. 2003. “Oharrak Determinatzaileen Inguruan: Oro-k Dioena”. J. M. Makatzaga \& B. Oyharçabal (arg), Euskal Gramatikari eta Literaturari Buruzko Ikerketak XXI. Mendearen Atarian Iker 14 (1). Bilbo: Euskaltzaindia, 137-159.

Azkarate, M., \& Altuna, P. 2001. Euskal Morfologiaren Historia. Donostia: Elkarlanean.

Barwise, J. \& Cooper, R. 1981. "Generalized quantifiers and natural language". Linguistics \& Philosophy 4: 159-219.

Brisson, C. 1998. Distributivity, Maximality, and Floating Quantifiers, Doktorego tesia. Rutgers University.

Brisson, C. 2003. "Plurals, all, and the nonuniformity of collective predication". Linguistics \& Philosophy 26: 129-184.

Büring, D. 1996. “A weak theory of strong readings”. T. Galloway \& J. Spence (arg), Proceedings of SALT 14. Dept. of Modern Languages, Cornell University, Ithaca, NY, 17-34.

Cappelen, H. \& Lepore, E. 2002. "Indexicality, binding, anaphora and a priori truth". Analysis: 271-281.

Cappelen, H. \& Lepore, E. 2005. Insensitive Semantics: A Defense of Semantic Minimalism and Speech Act Pluralism. London: Blackwell Publishers.

Carlson, G. \& Storto, G. agertzeko. "Sherlock Holmes was in no danger". B. Birner \& G. Ward (arg), Drawing the Boundaries of Meaning: Neo-Gricean Studies in Pragmatics and Semantics in Honor of Laurence R. Horn. Amsterdam: John Benjamins. 
Chierchia, G. 1998 "Plurality of mass nouns and the notion of "semantic parameter". S. Rothstein (arg), Events and Grammar. Dordrecht: Kluwer, 53-103.

Cooper, R. 1996. "The role of situations in generalized quantifiers". S. Lappin (arg), The Handbook of Contemporary Semantic Theory. Oxford: Blackwell, 65-86.

Diesing, M. 1992. Indefinites. Cambridge, MA: MIT Press.

Eguzkitza, A. 1997. "Kasuak eta postposizioak: deklinabidea eta postposiziobidea". Hizpide 40: 39-52.

Elordieta, A. 2001. Verb Movement and Constituent Permutation in Basque, Doktorego tesia. Leiden University.

Etxeberria, U. 2002a. "La Interpretación de los cuantificadores del Euskara". Interlingüistica 13 (II): 53-70.

Etxeberria, U. 2002b. Hacia la semántica de algunos determinantes cuantificacionales del Euskara. Eskuizkribua. EHU-UPV.

Etxeberria, U. 2004. "Do all quantifiers behave the same way compositionally?". A. Irurtzun \& U. Etxeberria (arg), Selected Proceedings of $1^{\text {st }}$ WoSS. VitoriaGasteiz: ASJU.EHU-UPV.

Etxeberria, U. 2005. Quantification and Domain Restriction in Basque, Doktorego tesia. EHU-UPV.

Euskaltzaindia. 1993. Euskal Gramatika Laburra: Perpaus Bakuna. Bilbo: Euskal Gramatika Batzordea.

von Fintel, K. 1994. Restrictions on Quantifier Domains. Doktorego tesia, UMass.

von Fintel, K. 1997. "Bare plurals, bare conditionals, and only". Journal of Semantics 14: $1-56$.

von Fintel, K. 1998. The semantics and pragmatics of quantifier domains. Eskuizkribua. MIT.

van Geenhoven, V. 1998 Semantic Incorporation and Indefinite Descriptions: Semantic and Syntactic Aspects of Noun Incorporation in West Greenlandic. Doktorego tesia, Universitaet Tuebingen

Giannakidou, A. 2004. "Domain restriction and the arguments of quantificational determiners". Proceedings of SALT 14. Dept. of Modern Languages, Cornell University, Ithaca, NY, 110-128

Giusti, G. 1991. "The categorical status of quantified nominals". Linguistiche Berichte 136: 438-454.

Goenaga, P. 1991. "Izen sintagmaren egituraz". J. Lakarra (arg), Memoriae L. Mitxelena Magistri Sacrum. Donostia: EHU-UPV, 847-865.

Haddican, B. 2001. "Basque functional heads". Linguistics in the Big Apple Working Papers in Linguistics.

Haddican, B. 2004. "Sentence polarity and word order in Basque". The Linguistic Review 21(2): 81-124.

Haddican, B. 2005. Aspects of Language Variation and Change in Contemporary Basque. Doktorego tesia, New York University.

Hamblin, C. L. 1973. "Questions in Montague English". Foundations of Language 10: 41-53.

de Hoop, H. 1992. Case Configuration and Noun Phrase Interpretation, Doktorego tesia. University of Groningen.

Hudson, W. 1989. "Functional categories and the saturation of noun phrases". NELS 19: 91-116. 
Huettner, A. 1984. Semantics Seminar Paper on 'few' and 'many'. Eskuizkribua. UMass.

Karttunen, L. 1973. "Presupposition of compound sentences". Linguistic Inquiry 4: 169-193.

Karttunen, L. 1979. "Syntax and semantics of questions". Linguistics \& Philosophy 1: 3-44.

Kayne, R. 1994. The Antisymmetry of Syntax. Cambridge, MA: MIT Press.

Keenan, E. L. \& Stavi, J. 1986. "A semantic characterization of natural language quantifiers". Linguistics \& Philosophy 9: 253-326.

Kratzer, A. 1998. "Scope or pseudoscope? Are there wide-scope indefinites?". S. Rothstein (arg), Events and Grammar. Dordrecht: Kluwer, 163-196.

Kratzer, A. 2004. "Covert quantifier domain restrictions". Milan Meeting-en emandako hitzaldia (Palazzo Feltrinelli, Gargnano).

Ladusaw, W. 1982. "Semantic constraints on the English partitive construction". D. Flickinger et al. (arg), Proceedings of WCCFL 1, 231-242.

Laka, I. 1990. Negation in Syntax: On the Nature of Functional Categories and Projections, Doktorego tesia. MIT.

Landman, F. 2002. "Predicate-argument mismatches and the adjectival theory of indefinites". Coene \& D'Hulst (arg), From NP to DP. Anvers.

Martí, L. 2003. Contextual Variables. Doktorego tesia, UConn.

Matthewson, L. 1999. "On the interpretation of wide-scope indefinites". Natural Language Semantics 7: 79-134.

Matthewson, L. 2001. "Quantification and the nature of crosslinguistic variation". Natural Language Semantics 9: 145-179.

Milsark, G. 1979. Existential Sentences in English. New York: Garland Publishing Inc.

Montague, R. 1973. "The proper treatment of quantification in ordinary English". J. Hintikka, J. Moravcsik, \& P. Suppes (arg), Approaches to Natural Language. Dordrecht: D. Reidel.

Muromatsu, K. 1998. On the Syntax of Classifiers, Doktorego tesia. University of Maryland.

Neale, S. 1990. Descriptions. Cambridge, MA: MIT Press.

Ortiz de Urbina, J. 1989. Parameters in the Grammar of Basque. Dordrecht: Foris.

Partee, B. H. 1987. "Noun phrase interpretation and type-shifting principles". J. Groenendijk, D. de Jongh, \& M. Stokhof (arg), Studies in Discourse Representation Theory and the Theory of Generalized Quantifiers. Dordrecht: Foris, 115-143.

Partee, B. H. 1988. "Many quantifiers”. J. Powers \& K. de Jong (arg), Proceedings of Fifth ESCOL. The Ohio State University, Columbus, 383-402.

Reinhart, T. 1997. "Quantifier scope: How labor is divided between QR and choice functions". Linguistics \& Philosophy 20: 335-397.

Ritter, E. 1991. "Two functional categories in noun phrases: Evidence from Modern Hebrew'. S. Rothstein (arg), Syntax and Semantics vol. 25. New York: Academic Press, 37-62.

Rooth, M. 1985. Association with Focus. Doktorego tesia, UMass.

Rooth, M. 1992. "A theory of focus interpretation". Natural Language Semantics 1: 75-116. 
Rodriguez, S. 2003. Euskal artikuluaren sintaxiaz. Eskuizkribua. EHU-UPV.

Russell, B. 1905. "On denoting". A. P. Martinich (arg), 2001. The Philosophy of Language. Oxford: Blackwell Publishers, 212-220.

van der Sandt, R. 1992. "Presupposition projection as anaphora resolution". Journal of Semantics 9: 333-377.

Stanley, J. 2002. "Nominal restriction”. G. Peters \& G. Preyer (arg), Logical Form and Language. Cambridge, MA: Oxford University Press, 365-388.

Stanley, J. \& Szabó, Z. G. 2000. "On quantifier domain restriction". Mind \& Language 15: 219-261.

Ticio, E. 1996. "El morfema -a en Vasco como marca de referencialidad". Interlingüística 7: 235-240.

Trask, L. 2003. "The noun phrase: nouns, determiners, and modifiers; pronouns and names". J.I. Hualde \& J. Ortiz de Urbina (arg), A Grammar of Basque. Dordrecht: Kluwer, 92-134.

Vangsness, Ø-A. 2001. "On noun phrase structure, referentiality, and article systems". Studia Linguistica 55: 249-299.

Westerståhl, D. 1985. "Logical constants in quantifier languages". Linguistics \& Philosophy 8: 387-413.

Winter, Y. 1997. "Choice functions and the scopal semantics of indefinites". Linguistics \& Philosophy 20: 399-467.

Zwicky, A. 1977. "On clitics”. Bloomington: Indiana University Linguistics Club.

Zwicky, A. 1985. "Clitics and particles". Language 61(2): 283-305. 